\title{
Effect of lactic acid supplementation on pancreatic secretion in pigs after weaning
}

\author{
M.-J. Thaela', M.S. Jensen', S.G. Pierzynowski', S. Jakob ${ }^{2}$ \\ and B.B. Jensen'
}

'Danish Institute of Agricultural Sciences, Department of Animal Nutrition and Physiology

P.O. Box 50,DK-3380 Tjele, Denmark

${ }^{2}$ Hohenheim University, Institute of Animal Nutrition (450)

D-70599 Stuttgart, Germany

\begin{abstract}
The effect of lactic acid supplementation to the starter diet, on pancreatic secretion in pigs after weaning was studied in three crossbred piglets (Duroc, Danish Landrace and Yorkshirc). The pigs were weaned at 28 days of age, and adapted to live in metabolic cages for one week, after which the piglets were surgically fitted with a pancreatic duct catheter and a duodenal $\mathrm{T}$-cannula for chronic collection of the pancreatic juice. Studies were then carried out over a period of three weeks, during which the piglets were fed three times a day (at $08.00,15.00$, and $22.00 \mathrm{~h}$ ). During period I, the piglets were fed with a standard weaner diet (control), during period II with a standard weaner diet supplemented with $2.5 \%$ lactic acid period (lactic acid) and during period III with a standard weaner diet (control). Beginning four days after surgery, samples of pancreatic juice were taken hourly from 08.00 to $16.00 \mathrm{~h}$. During period II, when lactic acid was added to the feed, the mean for all measured parameters of pancreatic secretion, except bicarbonate, increased in comparison to their values during period $\mathrm{I}$. However this increase was only significant for volume and protein content. In contrast, during period III, when lactic acid was removed, there were no statistically significant changes in any of the measured parameters of pancreatic secretion compared to their values in period II. Our data strongly indicate that dictary supplementation with lactic acid stimulates pancreatic secretion in piglets after weaning.
\end{abstract}

KEY WORDS: pig, pancreas, lactic acid, protein, trypsin, bicarbonate

\section{INTRODUCTION}

The performance of piglets is often poor during the first few weeks after weaning. It has been suggested that this postweaning lag phase may be partly related 
to an inability of the piglets to secrete sufficient endogenous digestive enzymes and gastric acid (Ravindran and Kornegay, 1993). Lindemann et al. (1986), and Pierzynowski et al. (1995) reported that piglets have insufficient pancreatic enzyme activity during the period shortly after weaning. One strategy that suckling pigs employ to overcome insufficient acid secretion, is the conversion of lactose, ingested in the sow's milk, to lactic acid, by lactobacilli bacteria. (Ravindran and Kornegay, 1993). Recent reports have shown that replacing feed antibiotics by acidifying agents in the diets for early weaned pigs may not only provide a prophylactic measure, but could be beneficial rather than harmful (Gabert and Sauer, 1994). Bearing all these facts in mind, our study attempts to determine the effect of adding lactic acid to the starter diet, on pancreatic secretion in pigs after weaning.

\section{MATERIAL AND METHODS}

Three crossbred piglets (Duroc, Danish Landrace and Yorkshire) were weaned at 28 days of age, and adapted to live in metabolic cages. Afterwards, the piglets were surgically fitted with a pancreatic duct catheter and a duodenal T-cannula for chronic collection of the pancreatic juice. During a period of three weeks, piglets were fed three times a day at $08.00,15.00$, and $22.00 \mathrm{~h}$. All the pigs received a standard weaner diet (control) during period I; a standard weaner diet supplemented with $2.5 \%$ lactic acid (lactic acid) during period II; and a standard weaner diet (control) during period III. Beginning four days after surgery, hourly samples of pancreatic juice were taken, from 08.00 to $16.00 \mathrm{~h}$. After measurement of the volume, approx. $1.5 \mathrm{ml}$ of pancreatic juice was stored for analysis and the rest of the juice was reintroduced into the duodenum. Protein, bicarbonate, and digestive enzymes in the pancreatic juice were measured utilising methods described by Jensen (1997).

\section{RESULTS AND DISCUSSION}

During period II, when lactic acid was added to the feed, the mean for all measured parameters of pancreatic secretion except bicarbonate, increased in comparison to their values during period I (Table 1). However this increase was only significant for volume and protein content. During period III, when lactic acid was removed, the mean values for all measured parameters of pancreatic secretion except bicarbonate, showed a tendency to decrease when compared to period II, although none of these decreases were statistically significant.

It was previously suggested that the growth promoting effects of organic acids could be the result of an increase in nutrient digestibility, a decrease in dietary $\mathrm{pH}$, 
TABLE 1

The mean and standard deviation for pancreatic juice variable, per unit body-weight ${ }^{0.75}$

\begin{tabular}{lccc}
\hline Period & I & II & III \\
\cline { 2 - 4 } Diet & control & lactic acid & control \\
\hline Volume, $\mathrm{ml} / \mathrm{kg}^{0.75} / \mathrm{h}$ & $5.4 \pm 0.5^{\mathrm{a}}$ & $7.3 \pm 0.6^{\mathrm{b}}$ & $6.6 \pm 0.7^{\mathrm{ab}}$ \\
Protein, $\mathrm{mg} / \mathrm{kg}^{0.75} / \mathrm{h}$ & $20.8 \pm 2.7^{\mathrm{a}}$ & $33.2 \pm 6.7^{\mathrm{h}}$ & $29.6 \pm 10.4^{\mathrm{ab}}$ \\
Trypsin, $\mathrm{U} / \mathrm{kg}^{0.75} / \mathrm{h}$ & $5.7 \pm 2.2^{\mathrm{a}}$ & $11.0 \pm 3.6^{\mathrm{ab}}$ & $10.0 \pm 0.5^{\text {bc }}$ \\
Chymotrypsin, $\mathrm{U} / \mathrm{kg}^{0.75} / \mathrm{h}$ & $158.7 \pm 43.5$ & $186.3+43.5$ & $171.9 \pm 42.9$ \\
Bicarbonate, $\mathrm{mmol} / \mathrm{kg}^{10.75} / \mathrm{h}$ & $1.2 \pm 0.6$ & $1.5 \pm 0.6$ & $1.3 \pm 0.5$ \\
\hline
\end{tabular}

$\mathrm{a}, \mathrm{b}, \mathrm{c}-$ within a row, mean values with different superscripts are significant different $(\mathrm{P}<0.05)$

a lowering of gastric $\mathrm{pH}$ and a decrease in bacterial growth (see Gabert and Sauer, 1994). Our data strongly indicate that lactic acid supplementation of feed for piglets after weaning stimulates pancreatic secretion. Furthermore, Ravindran and Kornegay (1993) reported that low $\mathrm{pH}$ in the stomach stimulates the secretion of pancreatic bicarbonate. However, in our studies bicarbonate secretion was almost unaffected by lactic acid supplementation, which makes it unlikely that the stimulation of pancreatic secretion observed was via a decrease in dietary and gastric $\mathrm{pH}$. More studies need to be conducted to elucidate the mechanism of this effect of lactic supplementation on pancreatic secretion

\section{REFERENCES}

Gabert V.M., Sauer W.C., 1994. The effects of supplementing diets for weanling pigs with organic acids. J. Anim. Feed Sci. 3, 73-87

Jensen M.S., Gabert V.M., Jørgensen H., Engberg R.M., 1997. Collection of pancreatic juice from growing pigs. Int. J. Pancreatol. 21, 173-184

Lindemann M.D., Cornelius S.G., El Kandelgy S.M., Moser R.L., Pettigrew J.E., 1986. Effect of age and diet on digestive enzyme levels in piglet. J. Anim. Sci. 62, 1298-1307

Pierzynowski S.G., Westrøm B.R., Svendsen J., Svendsen L., Karlsson B.W., 1995. Development and regulation of porcine pancreatic function. Int. J. Pancreatol. 18, 81-94

Ravindran V., Kornegay E.T., 1993. Acidification of weaner pig diets: A review. J. Sci. Food Agric. $62,313-322$ 